\title{
Financial Frictions and Export Dynamics in Large Devaluations
}

\author{
By David Kohn, Fernando Leibovici, and Michal Szkup* \\ Universidad Torcuato Di Tella, Argentina; York University, Canada; University of British \\ Columbia, Canada.
}

May 2015

\begin{abstract}
We study the role of financial frictions and balance-sheet effects in accounting for the dynamics of aggregate exports in large devaluations. In standard models of international trade, exports increase immediately following a large devaluation; in contrast, aggregate exports respond sluggishly in the data. We investigate a small open economy with heterogeneous firms and idiosyncratic productivity shocks, where firms face financing constraints and debt can be denominated in domestic or foreign units. In our model, a real depreciation affects firms through two channels. On the one hand, it increases the returns to selling internationally, making exporting more profitable. On the other hand, it tightens the borrowing constraint by increasing the value of foreign debt relative to firms' net worth. We calibrate the model to match key features from plant-level data and use it to quantify the importance of these channels. We find that financial frictions slow down the response of aggregate exports, and foreign-denominated debt amplifies this effect by decreasing firms' net worth on impact. When accounting for the observed heterogeneity in export intensity across exporters, these channels explain a large share of the gap between the data and the frictionless model.
\end{abstract}

\footnotetext{
*We thank Pablo Fajgelbaum, Juan Carlos Hallak, Kalina Manova, and seminar participants at Universidad Torcuato Di Tella, University of British Columbia, York University, Universidad de San Andrés, the Midwest Macroeconomics Meetings (St. Louis, MO), and the LACEA-IDB-CAF Trade, Integration and Growth Conference (UCLA), for helpful comments. We would also like to thank Germán Villegas Bauer for excellent research assistance. Emails: dkohn@utdt.edu, flei@yorku.ca, m.szkup@ubc.ca.
} 


\section{Introduction}

Financial crises are typically accompanied by both large slowdowns in economic activity and large devaluations of the domestic currency. A fundamental question in international macroeconomics concerns the extent to which large devaluations moderate or exacerbate the decline of key macroeconomic variables such as output, investment, and employment that are typically associated with these episodes.

While a large set of popular models of international trade, such as Eaton and Kortum (2002) and Melitz (2003), imply that large devaluations lead to sharp contemporaneous increases in aggregate exports, this prediction stands in stark contrast with the dynamics observed in these episodes. Specifically, Alessandria et al. (2014) document that aggregate exports increase gradually after a devaluation. This sluggish response of exports is important for explaining the contractionary effects of large devaluations, as documented by Edwards (1986), Kamin and Klau (1998), and Bebczuk et al. (2006).

The discrepancy between the predictions of standard models of international trade and the empirical evidence leads us to ask: what accounts for the dynamics of aggregate exports in episodes of large devaluations? In this paper, we study the role of frictions in financial markets and the currency denomination of debt in driving the slow response of aggregate exports following large devaluations.

When firms have foreign-denominated liabilities, a devaluation increases the value of their debt in terms of domestic currency, weakening their balance-sheets and forcing them to decrease investment and employment. In the theoretical literature, this channel is often referred to as the balance-sheet channel (see Aghion et al., 2000, Aghion et al., 2001, Aghion et al., 2004). Aguiar (2005) provides empirical evidence on the importance of balance-sheet

effects in accounting for the dynamics of exporters relative to non-exporters during the Mexican peso crisis of 1994.

We study a small open economy populated by a large number of entrepreneurs who trade with the rest of the world. Entrepreneurs produce differentiated goods by hiring labor to operate previously accumulated physical capital. The productivity of the production process is heterogeneous across entrepreneurs and changes over time following a stochastic process.

The first key ingredient of the model is access to international goods markets. We model international trade decisions as in Melitz (2003), where firms are subject to fixed and variable trade costs. Fixed costs are independent of the quantity exported, while variable trade costs capture not only tariffs, but also transportation costs and non-tariff barriers that are increasing in the amount exported.

The second key ingredient of the model is the interaction of frictions in financial markets 
with debt denominated in domestic and foreign units. We assume that entrepreneurs have access to two types of bonds that allow them to borrow or save at a given interest rate: a bond denominated in domestic units, and one denominated in foreign units. We make two key assumptions on the nature of their access to financial markets: (i) entrepreneurs face a borrowing constraint, which limits the amount that they can borrow; and (ii) a fixed fraction of their net wealth is allocated to bonds denominated in foreign goods.

In our model, an increase in the real exchange rate has offsetting effects on firms' export decisions. The first effect is a standard expansionary effect, that makes the domestic good cheaper and increases foreign demand. In response, there is an increase both in the number of firms exporting and the amount that they export. The second effect is the balance-sheet effect. An increase in the real exchange rate leads to an increase in the domestic value of total debt. As the value of collateral is denominated in domestic units, this tightens the borrowing constraint, leading to a decrease in investment and output. To the extent that the latter effect dominates on impact, this can account for the observed sluggish increase of aggregate exports.

In order to quantify the importance of these channels, we calibrate the model to match key cross-sectional moments of plant-level data and investigate the extent to which financial frictions together with balance-sheet effects can account for the dynamics of exports observed in the data following large real depreciations. ${ }^{1}$ In particular, we study the response of the economy to a sudden and unexpected increase in the real exchange rate caused by a sequence of shocks to the price of the foreign final good. We consider a situation where the economy is initially in a stationary equilibrium and firms expect that this situation will continue forever. When the price of the foreign good increases, agents learn its deterministic path to the new stationary equilibrium.

Consistent with the data, we assume that exporters differ in their export-intensity and consider two types of firms: (i) a fraction that only exports and accounts for the majority of aggregate exports; and (ii) a fraction of firms that can choose whether to export or not. Moreover, reflecting the evidence presented below, in the benchmark calibration we assume that firms that only export have all their debt denominated in foreign final goods while the remaining firms have all their debt denominated in domestic final goods.

To understand the role played by financial frictions and foreign denominated debt in our setup, we compare the response of aggregate exports across three different economies: (i) the benchmark calibration, with financial frictions and one type of firms that only export and only have access to foreign-denominated debt; (ii) an economy with financial frictions

\footnotetext{
${ }^{1}$ We refer to large devaluations and large real depreciations interchangeably. We are agnostic about the causes leading to an increase in the real exchange rate, and focus on its effects on aggregate exports.
} 
but without foreign-denominated debt; and (iii) an economy without financial frictions. For each of these economies, we solve the transitional dynamics between the initial and final steady states.

We find that financial frictions slow down the response of aggregate exports. Our results suggest that, without foreign-denominated debt, borrowing constraints can account, on impact, for 33 percent of the gap between the exports elasticity in the data and the frictionless model. When exporters have foreign-denominated debt, the model explains up to 45 percent of this gap. In this case, the real depreciation reduces the net worth of firms which amplifies the effects of the borrowing constraints.

Moreover, we show that these results depend on the nature of export intensity heterogeneity. In a model with financial frictions and foreign-denominated debt, but only one type of firms that can both export and sell domestically, aggregate exports adjust immediately to the change in the real exchange rate, as in the frictionless case. This is because, with only one type of firms, firms export only one-fourth of their total production and, hence, they are able to increase their exports considerably by decreasing their domestic sales without expanding their total productive capacity.

The remainder of this paper is organized as follows. In the rest of this section, we review the related literature. Section 2 presents evidence on the dynamics of the real exchange rate, aggregate exports, and credit following episodes of large devaluations. In Section 3, we introduce the model. Section 4 discusses the main mechanism and how a real depreciation affects aggregate exports in the model. Section 5 presents the quantitative findings. Section 6 concludes.

Related literature. Our paper is motivated by the recent findings reported in Alessandria et al. (2014), which show that exports tend to grow gradually following a devaluation. This observation stands in stark contrast to standard models of international trade in the spirit of Melitz (2003) and Eaton and Kortum (2002) that predict a large response of exports to changes in the real exchange rate.

Our explanation for the gradual response of exports is motivated by a large empirical literature that investigates the relationship between credit constraints, foreign denominated debt held by firms, and output, in episodes of currency crises. At the aggregate level, Céspedes (2005) and Bebczuk et al. (2006) find that devaluations in countries with a high fraction of foreign currency denominated debt have a strong negative impact on GDP growth. At the firm level, Aguiar (2005), Carranza et al. (2003), Galiani et al. (2003), Echeverry et al. (2003), and Benavente et al. (2003), report a negative impact of devaluations on investment in Mexico, Peru, Argentina, Colombia and Chile, respectively. Galindo et al. (2003) provides a summary of the firm level empirical evidence on the presence of balance-sheet effects in 
Latin American countries.

In addition, early contributions by Krugman (1999), Aghion et al. (2000), Aghion et al. (2001), Aghion et al. (2004), and Caballero and Krishnamurthy (2003), use stylized models to study the link between balance-sheet effects and the contractionary effects of large devaluations.

Our model builds on the framework that we developed in earlier papers (Kohn et al., 2015, and further extended in Leibovici, 2015) and is related to quantitative work that explores the connection between exchange rate regimes and financial distress in economies with credit constraints (see Céspedes et al., 2003, Céspedes et al., 2004, Devereux et al., 2006, and Gertler et al., 2007). Pratap and Urrutia, 2004 investigate the role of credit constraints and international trade in accounting for output and investment dynamics in a partial equilibrium setup. More broadly, our work contributes to a rapidly growing theoretical and quantitative literature that studies the effects of financial frictions on export decisions, such as Chaney (2013), Caggese and Cunat (2013), Manova (2013), or Kohn et al. (2015).

Alternative explanations have been proposed for the gradual response of exports following a devaluation. Alessandria et al. (2014) points towards the presence of sunk costs and their discouraging effect on export entry following a large devaluation. More broadly, Frankel (2005) lists several other factors that can lead to a contraction in economic activity such as an increase in the prices of imports (see also Cooper, 1971). However, Frankel (2005) argues that most of these effects are unlikely to explain the macroeconomic behavior following a devaluation, and claims that balance-sheet effects should receive the most emphasis.

\section{Data}

In this section, we document the facts that motivate our subsequent analysis. We start by investigating the dynamics of real exchange rates and aggregate exports in a sample of large devaluations over the last three decades. Next, we present evidence on the currency composition of debt at the aggregate level across countries, and across exporters and nonexporters using Peruvian firm-level data. Finally, we examine the dynamics of aggregate credit during large devaluations.

\subsection{Real exchange rate and export dynamics in large devaluations}

We begin by investigating the dynamics of the real exchange rate and real exports following large real devaluations. To identify devaluations, we use real effective exchange rate data compiled by the Bank for International Settlements (BIS), and define a large real devaluation 
as an increase in the real effective exchange rate of at least $20 \%$ within a year. ${ }^{2}$ The data on real exports comes from the International Financial Statistics (IFS) database published by the International Monetary Fund (IMF). We restrict our attention to the period from 1980 to $2013 .^{3}$

Using our above definition, we identify 15 episodes of large devaluations in our dataset. These include: Argentina (2002), Brazil (1999), Denmark (1999), Iceland (2008), Japan (2013), South Korean (1998), Malaysia (1998), Mexico (1982, 1986, 1994), Russia (1999) and Venezuela $(2002,2010)$. In what follows, we drop Japan (because of insufficient data following the devaluation) and Russia (because of missing export data prior to the devaluation) leaving us with 13 devaluation episodes. ${ }^{4}$
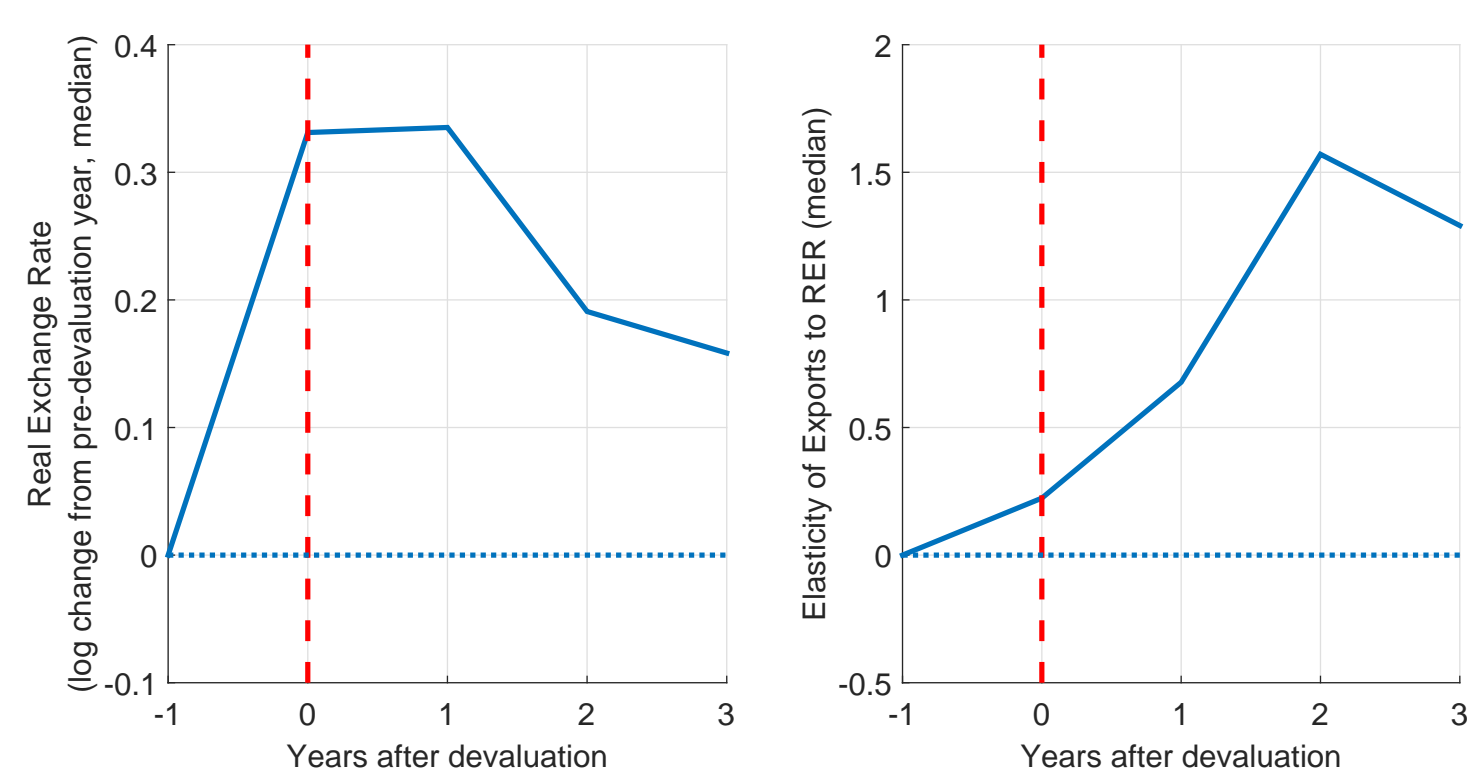

Source: The exchange rate data from the BIS effective exchange rate dataset. The export data from the International Financial Statistics (IFS) database published by the IMF.

\section{Figure 1: Aggregate dynamics of RER and real exports}

In Figure 1, we plot the median log-change of the real exchange rate relative to the predevaluation level (left panel) and the median elasticity of real exports to changes in the real exchange rate (right panel). ${ }^{5}$ We see that, following a devaluation, the median exchange rate

\footnotetext{
${ }^{2}$ For each country the real effective exchange rate is defined as a weighted average of bilateral exchange rates adjusted with the corresponding relative consumer prices. See Klau and Fung (2006), "The new BIS effective exchange rate indices", BIS Quarterly Review.

${ }^{3}$ Real exchange rate data are reported at quarterly frequency. To aggregate the exchange rate data into yearly frequency, we take an average of the real exchange rate across every quarter within a given year.

${ }^{4}$ The results presented below are robust to alternative thresholds for the definition of a large devaluation.

${ }^{5}$ More precisely, in the right panel we plot the median $\log \left(\xi_{t}\right) / \log \left(\xi_{-1}\right)$ for where $\xi_{t}$ is the real exchange rate at time $t$ and $\xi_{-1}$ corresponds to the year just before the devaluation. In the left panel, we plot
} 
increases by approximately $34 \%$ and it stays at this level for another year, before decreasing steadily over the following two years. However, even after four years the median exchange rate is almost $16 \%$ higher than the pre-devaluation level.

The right panel of Figure 1 shows that, despite the large change in the real exchange rate, real exports increase only gradually following a devaluation. The exports elasticity peaks at two years after the devaluation at the level of 1.7, before declining in the following year. Moreover, the median export elasticity in the year of the devaluation is only 0.2 , less than $15 \%$ of its peak value. Thus, Figure 1 shows that real exports respond slowly to sharp and sudden changes in the real exchange rate. This stands in stark contrast to standard trade models (such as Melitz (2003) or Eaton and Kortum (2002)) which predict a sharp increase in exports following a devaluation.

\subsection{Currency composition of debt}

Currency composition of debt across countries In this section, we document the extent to which the countries that experienced large devaluations relied on debt denominated in foreign currency. To do so, we use the International Currency Exposure data constructed by Lane and Shambaugh (2007). This dataset covers 117 countries and contains detailed estimates of each country's currency exposure for every year between 1990 and 2004. In what follows, we restrict our attention to the thirteen countries we considered above and focus on their overall reliance on foreign denominated debt. ${ }^{6}$

We report the results in Table 1 . We observe that, at the time of the devaluation, all the countries in our sample had a significant amount of foreign currency debt, both relative to the total debt in the economy and to their GDP. In particular, the median ratio of debt denominated in foreign currency to total debt was almost $72 \%$ while the median ratio of debt in foreign currency to GDP was about 43\% (the respective averages were $70 \%$ and $52 \%$ ). These findings imply that a devaluation, by increasing these countries' debt burden in terms of domestic currency, could potentially have a negative effect on these economies. Finally, note that our finding of a high degree of international currency exposure is similar to earlier results reported in the literature that document high levels of currency mismatch in developing economies (e.g., Hausmann and Panizza, 2003, or Goldstein and Turner, 2005).

While Table 1 shows that a typical country that experienced a large devaluation in the

$\log \left(X_{t} / X_{-1}\right) / \log \left(\xi_{t} / \xi_{-1}\right)$ where $X_{t}$ are exports at time $t$ and $X_{-1}$ corresponds to the year just preceding the devaluation.

${ }^{6}$ Note that three of the devaluations in our sample (Mexico 1982, Mexico 1986 and Venezuela 2010) occurred outside of the span of Lane and Shambaugh (2007) data. For the case of the Mexican devaluations in 1982 and 1986, we use data from 1990, the first year in the dataset. For the case of Venezuela in 2010, we use the data corresponding to year 2004, the last year in the dataset. 


\section{Table 1: Currency composition of debt across countries}

\begin{tabular}{ccccc}
\hline \hline & Country & Year & \% of debt in foreign currency & Debt in foreign currency / GDP (\%) \\
\hline 1 & Argentina & 2002 & 70.97 & 56.64 \\
2 & Brazil & 1999 & 59.83 & 33.33 \\
3 & Denmark & 1998 & 74.79 & 100.65 \\
4 & Iceland & 2008 & 92.97 & 86.92 \\
5 & Indonesia & 1998 & 86.79 & 68.62 \\
6 & Korea & 1998 & 71.03 & 25.53 \\
7 & Malaysia & 1998 & 41.52 & 42.73 \\
8 & Mexico & 1982 & $76.35^{*}$ & $39.76^{*}$ \\
9 & Mexico & 1986 & $76.35^{*}$ & $39.76^{*}$ \\
10 & Mexico & 1995 & 71.88 & 58.65 \\
11 & Turkey & 2001 & 87.27 & 51.78 \\
12 & Venezuela & 2002 & 51.77 & 36.59 \\
13 & Venezuela & 2010 & $50.27^{* *}$ & $34.79^{* *}$ \\
\hline & Average & & 70.14 & 51.98 \\
& Median & & 71.88 & 42.73 \\
\hline \hline
\end{tabular}

Source: International Currency Exposure data introduced in Lane and Shambaugh (2007). ${ }^{*}$ data for the year 1990. ${ }^{* *}$ data for the year 2004 .

last three decades had significant international currency exposure, it is silent on whether the exposure was concentrated in the private or the public sector of the economy. Thus, in the next section, we investigate whether the same observation holds at the firm level.

Currency composition of debt by export status Given our interest in understanding the dynamics of exports in large devaluation, we now examine the currency composition of debt by export status. While, ideally, one would focus on the large devaluation episodes examined above, such data is not widely available. Therefore, for this subsection, we restrict attention to the currency composition of debt between exporters and non-exporters in Peru. While Peru didn't experience a large devaluation (according to the definition above) over the past decades, it is an emerging economy that is in many other dimensions similar to the ones that did experienced one. 
We combine two large datasets. The first dataset consists of the universe of bank loans to Peruvian firms issued by banks that operate in Peru. In particular, we observe the currency denomination of each of the loans. This data is collected by the Superintendence of Banking, Insurance and Pensions (the Peruvian banks' regulator). The second dataset consists of the universe of Peruvian export transactions, collected by the Peruvian customs agency. Given the availability of firm tax identifiers, we are able to merge the two datasets to end up with a dataset for year 2005 which contains information on debt denomination and export status for every Peruvian exporter as well as for every Peruvian firm that has a non-zero loan. For a more detailed description of these datasets, see Paravisini et al. (2015).

Table 2: Share of foreign-denominated debt by export status

\begin{tabular}{cccc}
\hline \hline Median & Credit & Loans & Trade Credit \\
\hline All & 0.78 & 0.66 & 0.76 \\
Non-exporters & 0.76 & 0.66 & 0.71 \\
Exporters & 0.96 & 0.70 & 0.85 \\
\hline \hline
\end{tabular}

Source: The bank and loan data from the Superintendence of Banking, Insurance and Pensions (SBS) for years 2004 to 2006 .

We observe that Peruvian firms tend to rely heavily on credit denominated in foreign currency. A median firm tends to have $78 \%$ of its debt, $66 \%$ of its loans, and $76 \%$ of its trade credit denominated in foreign currency. Moreover, we see that the fraction of foreign denominated debt, loans, and trade credit is significantly higher among exporters compared to non-exporters. A median exporter tends to have an $18 \%$ higher fraction of its credit denominated in foreign currency compared to a median non-exporter. The corresponding differences for the fractions of loans and trade credit denominated in foreign currency are $4 \%$ and $14 \%$, respectively. Thus, to the extent that Peruvian firms are representative of typical firms in small open economies, Table 2 suggests that firms in small open economies tend to borrow heavily in foreign currency and that exporters have a higher fraction of foreign-denominated debt than non-exporters.

\subsection{Debt dynamics in large devaluations}

The evidence presented above shows that countries which experienced large devaluations over the past few decades also had a large share of their total debt denominated in foreign currency. In addition, we documented that, in an emerging economy similar to the ones that 
experienced large devaluations, exporters hold a large share of debt in foreign currency, with this share large than that of non-exporters.

We now conclude this section by investigating the dynamics of total debt, or credit, during these episodes of large devaluations. To do so, we use data on total debt held by the private non-financial sector. This data is collected by the BIS, and is measured in domestic currency. Therefore, to the extent that a large share of debt is denominated in foreign currency, a large devaluation should lead to a significant increase in the amount of debt faced by firms in these economies.

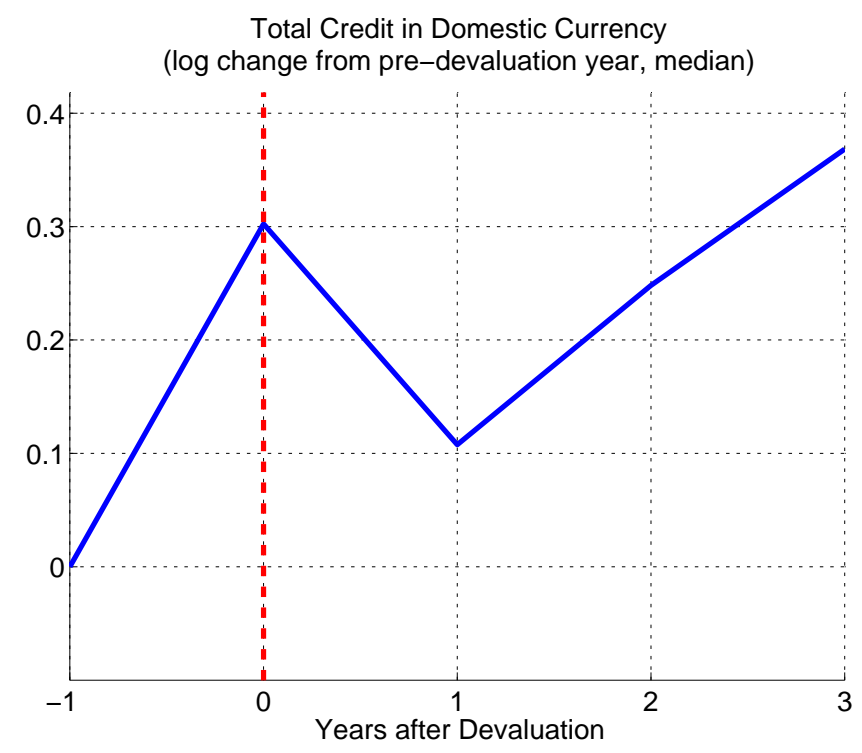

Figure 2: Aggregate debt dynamics

In Figure 2, we plot the median log-change of total credit relative to the pre-devaluation level. The figure shows that the median increase in the domestic value of total credit during the year of a large devaluation is larger than $30 \%$. To the extent that this increase in the domestic value of credit results from the currency denomination of debt, we conjecture that it could be the driver of the slow response of exports in these episodes. We investigate this conjecture systematically in the following sections. After the devaluation, this value decreases transitorily in the following year, and then continues to increase steadily up to three years after the large change in the real exchange rate.

\section{Model}

The model consists of an economy populated by a unit measure of entrepreneurs and final good producers who trade with the rest of the world. There are three types of goods in the 
economy: final goods, domestic intermediates, and foreign intermediates. Final goods are produced by final good producers and used by entrepreneurs for consumption and investment. Domestic intermediates are produced by entrepreneurs and sold to final good producers and the rest of the world. Finally, foreign intermediates are produced by the rest of the world and sold to final good producers. Only intermediate goods can be traded internationally.

\subsection{Economic environment}

\subsubsection{Entrepreneurs}

Preferences Entrepreneurs are risk averse, with preferences over streams of consumption of final goods. Preferences are represented by the expected lifetime discounted sum of a constant relative risk aversion period utility function, $\mathbb{E}_{0} \sum_{t=0}^{\infty} \beta^{t} \frac{c_{t}^{1-\gamma}}{1-\gamma}$, where $\gamma$ denotes the coefficient of relative risk aversion, $\beta$ is the subjective discount factor, and $\mathbb{E}_{0}$ denotes the expectation operator taken over the realizations of a productivity shock that is described below, conditional on the information set in period zero.

Technology Entrepreneurs produce differentiated intermediate goods by operating a constant returns to scale production technology $y_{t}=z_{t} k_{t}^{\alpha} n_{t}^{1-\alpha}$, where $z_{t}$ denotes an idiosyncratic level of productivity, $k_{t}$ is the capital stock, $n_{t}$ is the amount of labor hired, and $\alpha \in(0,1)$ is the capital share. Labor is hired at a wage $w_{t}$ in terms of final goods. Idiosyncratic productivity $z_{t}$ follows a time invariant $\operatorname{AR}(1)$ process $\ln z_{t}=(1-\rho) \mu+\rho \ln z_{t-1}+\varepsilon_{t}$, where $\varepsilon_{t}$ is distributed according to a Normal distribution with mean zero and standard deviation $\sigma_{\varepsilon}$.

Every period entrepreneurs are endowed with a unit of labor that is supplied inelastically to other entrepreneurs through a competitive labor market. Capital is accumulated internally by transforming final goods invested in period $t$ into physical capital in period $t+1$. Capital depreciates at rate $\delta$ after being used for production, leading to a law of motion for capital that is given by $k_{t+1}=(1-\delta) k_{t}+x_{t}$.

International trade Entrepreneurs can trade internationally conditional on payment of export-entry costs and variable trade costs. A firm's export choice at time $t$ is denoted by $e_{t}$, and is equal to one if the firm exports in period $t$, and is zero otherwise. Firms have to pay a fixed cost $F$ every period that they decide to export. Furthermore, exporters are subject to an ad-valorem trade cost $\tau>1$, which requires firms to ship $\tau$ units for every unit that arrives at destination. Every cost is expressed in terms of the final good. 
Financial markets Entrepreneurs have access to financial markets, where they can borrow or save by trading a one-period risk-free bond at a real interest rate $r_{t}$. A firm that chooses to borrow a total amount $\frac{d_{t+1}}{1+r_{t}}$ allocates a fraction $\lambda$ to debt denominated in domestic goods, and a fraction $1-\lambda$ to debt denominated in foreign goods. With the real exchange rate $\xi_{t}$ denoting the price of a foreign good in terms of a domestic final good, ${ }^{7}$ the total amount of foreign goods borrowed is equal to $\frac{d_{t+1}}{1+r_{t}} \frac{1-\lambda}{\xi_{t}}$. In the following period, the firm repays $\lambda d_{t+1}$ for domestic-denominated debt, and $(1-\lambda) d_{t+1} \frac{\xi_{t+1}}{\xi_{t}}$ for debt denominated in foreign goods.

Entrepreneurs face a borrowing constraint, which limits the amount that they can borrow to a fraction $\theta$ of the value of the capital stock at the time that the loan is due for repayment. Thus, while entrepreneurs can trade this bond to save as much as they desire, their borrowing amount $d_{t+1}$ has to satisfy $d_{t+1}\left[\lambda+(1-\lambda) \frac{\xi_{t+1}}{\xi_{t}}\right] \leq \theta k_{t+1}$ and the natural borrowing limit.

Market structure Entrepreneurs compete with each other under monopolistic competition, and choose the quantities and prices at which to sell in each market subject to their respective demand schedules. In the domestic market, the demand schedule is such that it solves the final good producer's problem, while the demand schedule faced in the international market is given by the rest of the world. Denote the quantities and prices of intermediate goods sold in the domestic market by $y_{h, t}$ and $p_{h, t}$, and those sold in the foreign market by $y_{f, t}$ and $p_{f, t}$, respectively. The price of intermediate goods sold to the rest of the world, $p_{f, t}$, is denominated in units of the foreign final good.

States $k_{t}, d_{t}$, and $z_{t}$

Choose $e_{t}, y_{h, t}$, and $y_{f, t}$

Choose $c_{t}$ and $a_{t+1} \quad$ Observe $z_{t+1} \quad$ Choose $k_{t+1}, d_{t+1}$, out of $a_{t+1}$

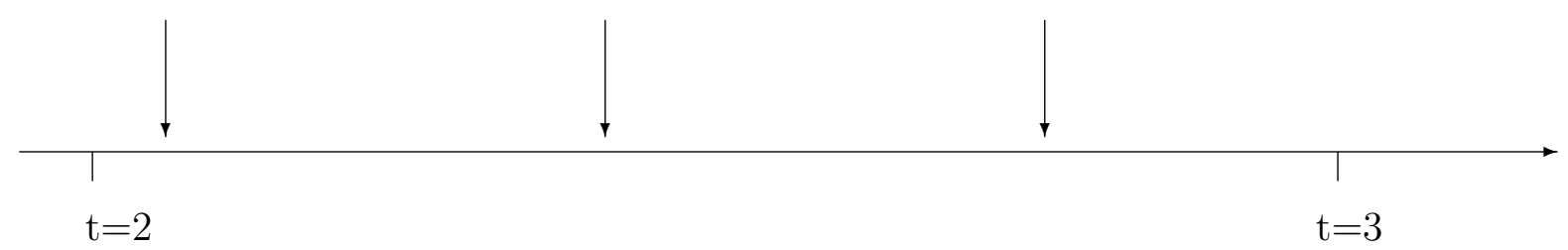

\section{Figure 3: Timing}

${ }^{7}$ The real exchange rate is $\xi \equiv \xi_{\text {nominal }} \frac{P_{f}}{P}$. Since $\xi_{\text {nominal }}$ does not affect real quantities in our model, we set it to 1. 
Timing The timing of entrepreneurs' decisions is as follows. Entrepreneurs begin the period by hiring labor, producing their variety of the intermediate good, and then selling it in each of the markets in which they choose to operate. If they decide to export, $e=1$, then they also pay the fixed export costs. At the same time, they repay their old debt and decide how much net worth, $a$, to carry over to the following period. At the end of the period, they observe the following period's productivity shock. Then, they simultaneously issue new debt and choose their new level of physical capital. Figure 3 presents the timing of the entrepreneurs' problem.

Entrepreneurs' problem Given this setup, the entrepreneurs' problem at time $t$ consists of choosing sequences of consumption $c_{t}$, labor $n_{t}$, investment $x_{t}$, current period's export status $e_{t+1}$, and prices and quantities $y_{h, t}, p_{h, t}, y_{f, t}, p_{f, t}$ at which to sell the intermediate goods in each of the markets, in order to maximize their expected utility. In addition to the borrowing constraint described above and the market-specific demand schedules that are described below, their choices are subject to a sequence of period-by-period budget constraints, law of motion for capital $k_{t+1}=\left[(1-\delta) k_{t}+x_{t}\right]$, and production technology $y_{h, t}+\tau y_{f, t}=z_{t} k_{t}^{\alpha} n_{t}^{1-\alpha}$. Their budget constraint in period $t$ is given by:

$$
\begin{aligned}
& P_{t} c_{t}+P_{t} x_{t}+P_{t} d_{t}\left[\lambda+(1-\lambda) \frac{\xi_{t}}{\xi_{t-1}}\right]+ e_{t} P_{t} F= \\
& P_{t} w_{t}+P_{t} p_{h, t} y_{h, t}+e_{t} P_{t} \xi_{t} \frac{p_{f, t}}{P_{t}^{*}} y_{f, t}-P_{t} w_{t} n_{t}+\frac{P_{t} d_{t+1}}{1+r_{t}}
\end{aligned}
$$

where $P_{t}$ denotes the price of the final good. Dividing this expression by the price of the domestic final good, this budget constraint can be rewritten as:

$$
\begin{aligned}
& c_{t}+x_{t}+d_{t}\left[\lambda+(1-\lambda) \frac{\xi_{t}}{\xi_{t-1}}\right]+e_{t} F= \\
& w_{t}+p_{h, t} y_{h, t}+e_{t} \xi_{t} \frac{p_{f, t}}{P_{f, t}} y_{f, t}-w_{t} n_{t}+\frac{d_{t+1}}{1+r_{t}}
\end{aligned}
$$

\subsubsection{Final good producers}

Final good producers purchase intermediates from entrepreneurs and the rest of the world, and aggregate them to produce a final good. They operate a constant elasticity of substitution (CES) technology with elasticity of substitution $\sigma>1$. Let the set $[0,1]$ index the unit measure of entrepreneurs in the economy, and let $\left\{p_{h, t}(i)\right\}_{i \in[0,1]}$ and $p_{m, t}$ be the prices of intermediate goods charged by the entrepreneurs and the rest of the world, respectively. ${ }^{8}$ Given

\footnotetext{
${ }^{8} p_{m, t}$ is denominated in units of the foreign good
} 
these prices, final good producers choose the bundle of inputs of domestic and imported intermediates, $\left\{y_{h, t}(i)\right\}_{i \in[0,1]}$ and $y_{m, t}$, that maximizes their profits. Then, the problem of final good producers is given by:

$$
\max _{y_{h, t}(i), y_{m, t}} P_{t} Y_{t}-\int_{0}^{1} P_{t} p_{h, t}(i) y_{h, t}(i) d i-P_{t} \xi_{t} \frac{p_{m, t}}{P_{f, t}} y_{m, t}
$$

subject to

$$
Y_{t}=\left[\int_{0}^{1} y_{h, t}(i)^{\frac{\sigma-1}{\sigma}} d i+y_{m, t}^{\frac{\sigma-1}{\sigma}}\right]^{\frac{\sigma}{\sigma-1}},
$$

where $p_{t}$ and $y_{t}$ denote the price and quantity of the final good, respectively.

The solution to this problem is given by $y_{h, t}(i)=\left(p_{h, t}(i)\right)^{-\sigma} Y_{t}$ and $y_{m, t}=\left(\xi_{t} \frac{p_{m, t}}{P_{f, t}}\right)^{-\sigma} y_{t}$, which are the demand schedules faced by entrepreneurs and the rest of the world, respectively. The aggregate price index satisfies

$$
1=\left[\int_{0}^{1}\left(p_{h, t}(i)\right)^{1-\sigma} d i+\left(\xi_{t} \frac{p_{m, t}}{P_{f, t}}\right)^{1-\sigma}\right]^{\frac{1}{1-\sigma}}
$$

\subsubsection{Rest of the world}

The rest of the world demands intermediates from entrepreneurs - the domestic economy's exports- and supplies intermediates to final good producers - the domestic economy's imports. The foreign demand for intermediates produced by entrepreneurs is assumed to be given by a downward-sloping demand function with the same constant elasticity of substitution $\sigma, y_{f, t}=\left(\frac{p_{f, t}}{P_{f, t}}\right)^{-\sigma} Y_{f, t}$, where $Y_{f, t}$ and $P_{f, t}$ denote the aggregate quantity and price indexes of the rest of the world, and $\frac{p_{f, t}}{P_{f, t}}$ is denominated in units of the foreign good. The supply of intermediates from the rest of the world, imported by final good producers, is assumed to be perfectly elastic at price $p_{m, t}=\bar{p}_{m}$. Finally, we set the nominal exchange rate to 1 , so that $\xi_{t}=\frac{P_{f, t}}{P_{t}}$.

\subsection{Entrepreneur's problem: Recursive formulation}

Let $v(k, d, z)$ be the value function for an entrepreneur with capital $k$, debt $d$, and productivity $z$, who is making consumption and saving decisions, and production decisions for the foreign and domestic markets. ${ }^{9}$ Let $g(a, z)$ be the value for an entrepreneur with net worth $a$ and productivity $z$, who decides how much capital $k$ and debt $\frac{d}{1+r}$ carry on to the next period.

${ }^{9}$ The value of debt is actually $d\left[\lambda+(1-\lambda) \frac{\xi}{\xi-1}\right]$ 
Then, the entrepreneur's problem can be described as:

$$
v(k, d, z)=\max _{c, n, a^{\prime}, p_{h}, p_{f}, y_{h}, y_{f}, e \in\{0,1\}} \frac{c^{1-\gamma}}{1-\gamma}+\beta \mathbb{E}_{z^{\prime}}\left[g\left(a^{\prime}, z^{\prime}\right)\right]
$$

subject to

$$
\begin{aligned}
& c+a^{\prime}+d\left[\lambda+(1-\lambda) \frac{\xi}{\xi_{-1}}\right]+w n+e F=w+p_{h} y_{h}+e \xi \frac{p_{f}}{P_{f}} y_{f}+(1-\delta) k \\
& y_{h}+\tau y_{f}=z k^{\alpha} n^{1-\alpha}, \quad y_{h}=\left(p_{h}\right)^{-\sigma} y, \quad y_{f}=\left(\frac{p_{f}}{P_{f}}\right)^{-\sigma} Y_{f}
\end{aligned}
$$

and:

$$
\begin{aligned}
& g\left(a^{\prime}, z^{\prime}\right)=\max _{k^{\prime}, d^{\prime}} v\left(k^{\prime}, d^{\prime}, z^{\prime}\right) \\
& \text { subject to } \\
& a^{\prime}=k^{\prime}-\frac{d^{\prime}}{1+r} \\
& d^{\prime}\left[\lambda+(1-\lambda) \frac{\xi^{\prime}}{\xi}\right] \leq \theta k^{\prime}
\end{aligned}
$$

\subsection{Equilibrium}

Let $\mathcal{S}:=\mathcal{K} \times \mathcal{D} \times \mathcal{Z}$ denote the state space of entrepreneurs, where $\mathcal{K}=\mathbb{R}^{+}, \mathcal{D}=\mathbb{R}$, and $\mathcal{Z}=\mathbb{R}^{+}$denote the set of possible values of capital, debt, and productivity, respectively. Finally, let $s \in \mathcal{S}$ denote an element of the state space.

For a given value of the interest rate $r$, a recursive stationary competitive equilibrium of this economy consists of prices $\{w, P, \xi\}$, policy functions $\left\{d^{\prime}, k^{\prime}, e, c, n, y_{d}, y_{f}, p_{d}, p_{f}, Y, y_{m}\right\}$, a value function $v$, a value function $g$, and a measure $\phi: \mathcal{S} \rightarrow[0,1]$ such that:

1. Policy and value functions solve the entrepreneurs' problem;

2. Policy functions solve the final good producers' problem;

3. Labor market clears: $\int_{\mathcal{S}} n(s) \phi(s) d s=1$;

4. Final good market clears: $\int_{\mathcal{S}}[c(s)+x(s)+e F] \phi(s) d s=Y$;

5. Measure $\phi$ is stationary. 


\section{Mechanism}

In this section, we study the mechanism through which changes in the real exchange rate affect aggregate exports in our model. To do so, we first examine the determinants of aggregate exports in a stationary equilibrium, focusing on the impact of financial frictions and foreign-denominated debt. We then investigate the channels through which a large devaluation affects aggregate exports, and examine their net impact on aggregate export dynamics.

\subsection{Aggregate exports in a stationary equilibrium}

In a stationary equilibrium, aggregate exports in units of foreign final goods are given by:

$$
\text { Exports }=\int_{s \in \mathcal{S}_{x}} \frac{p_{f}(s) y_{f}(s)}{P_{f}} \varphi(s) d s,
$$

where $\mathcal{S}_{x}:=\{s \in \mathcal{S} \mid e(s)=1\}$ denotes the set of firms that choose to export, and $\frac{p_{f}(s) y_{f}(s)}{P_{f}}$ denotes the value of exports in units of foreign final goods produced by an entrepreneur in state $s \in \mathcal{S}_{x}$. As we explain below, financial frictions distort aggregate exports along the intensive and extensive margins of international trade. On the other hand, the presence of foreign-denominated debt has no effect on the stationary equilibrium outcomes.

Firm-level exports Along the intensive margin, financial frictions and foreign-denominated debt reduce the volume of goods exported by firms with a binding borrowing constraint. To the extent that some firms cannot borrow as much as desired, they are forced to operate with a sub-optimal amount of physical capital, producing a sub-optimal amount of goods, and reducing their level of exports.

To see this, consider an entrepreneur with capital stock $k$, debt level $d$, and productivity $z$. The volume that such entrepreneur chooses to export, in units of foreign final goods, is given by:

$\log \frac{p_{f} y_{f}}{P_{f}}=\log \Phi+(\sigma-1)[\log z-(1-\alpha) \log w]+(\sigma-1)[\log \xi-\alpha \log (\widetilde{r}+\delta+\mu(1+\widetilde{r}-\theta))]$

where $\widetilde{r}$ denotes the effective real interest rate, $\mu$ is the Lagrange multiplier on the entrepreneurs' borrowing constraint, and $\Phi:=\left[\frac{\sigma}{\sigma-1} \frac{\tau}{\alpha^{\alpha}(1-\alpha)^{1-\alpha}}\right]^{1-\sigma} Y_{f}$ is a constant that is a function of parameters. The effective real interest rate $\widetilde{r}$, denominated in units of domestic goods, is given by $1+\widetilde{r}=(1+r)\left[\lambda+(1-\lambda) \xi / \xi_{-1}\right]$, and represents the return to saving 
a unit of domestic goods through the financial market. Since in the stationary equilibrium $\xi=\xi_{-1}$, the above equation implies that debt-denomination does not affect foreign sales in this case.

As in a large class of models of international trade with heterogeneous firms and monopolistic competition, firm-level exports are increasing in productivity $z$ and decreasing in the cost of labor $w$. Given the downward-sloping demand faced by exporters in the foreign market, more productive firms find it profitable to export a larger volume of goods. Similarly, higher labor costs decrease the volume of goods that firms find profitable to export.

In addition, firm's foreign sales are increasing in the real exchange rate $\xi$, and decreasing in the implicit rental rate of capital $\widetilde{r}+\delta+\mu(1+\widetilde{r}-\theta)$, which consists of the opportunity cost of investing in physical capital. This opportunity cost is given by the return that the entrepreneur would obtain if he invested in the bond rather than in physical capital. In particular, in the former case the entrepreneur would earn a return $\widetilde{r}$, save the depreciation $\operatorname{cost} \delta$ and relax his borrowing constraint with an implicit benefit captured by the lagrange multiplier $\mu$.

In a stationary equilibrium, financial frictions reduce firm-level exports as long as the borrowing constraint binds, $\mu>0$, by increasing the implicit rental rate of capital faced by entrepreneurs. In this case, the return to investing in the bond is higher than the effective interest rate $\widetilde{r}$, since it additionally relaxes the borrowing constraint. Therefore, since in equilibrium firms require the same return to investing in physical capital and investing in the bond, in the presence of financial frictions firms choose to accumulate a lower amount of capital. The lower level of capital in the economy with financial frictions implies that firms produce and export less output than in the economy without financial frictions. ${ }^{10}$

Set of exporters Along the extensive margin, financial frictions distort the set of firms that choose to export, reducing the share of firms that find it profitable to do so. To understand why this is the case, consider first an economy without financial frictions $(\theta=\infty)$. Given that entrepreneurs observe their next period productivity when making the investment decision, it follows that in the frictionless economy firms always operate with the optimal level of capital. Therefore, as in standard models of international trade with endogenous export entry decisions, firms choose to export to the extent that their productivity is large enough to make it profitable to pay the fixed export costs. If their productivity is not high enough, they choose to sell only in the domestic market.

In contrast, with financial frictions, firms with high productivity but a low level of net

\footnotetext{
${ }^{10}$ Note that, as shown by Leibovici (2015), financial frictions also affect firm-level exports through their effect on the equilibrium wage. The quantitative analysis below will take into account this effect, although for ease the exposition we abstract from it in this section.
} 
worth do not find it profitable to export. This is because low net worth prevents them from accessing sufficient internal or external funds to increase the following period's capital stock to its optimal level. Even though it would be profitable for these firms to pay the fixed export cost in the frictionless economy, they choose not to export in the economy with financial frictions since they cannot achieve a sufficiently high scale of production necessary to make exporting profitable. Therefore, in this economy the set of firms that choose to export is distorted relative to the frictionless economy, featuring a lower share of exporters.

Note that, as with the intensive margin, given that $\xi=\xi_{-1}$ in a stationary equilibrium, the foreign-denomination of debt does not impact firms' export entry decisions in this case.

\subsection{Large devaluation and aggregate exports}

We now investigate the impact of a large devaluation on aggregate exports -that is, an unexpected increase in the real exchange rate $\xi$. Consider first an economy without financial frictions $(\theta=\infty)$. In this economy a devaluation increases exports through two channels. First, a devaluation increases exports through the intensive margin of trade as firms that were already exporting increase their foreign sales in response to higher foreign demand for domestic intermediate goods. Second, by making the foreign market more attractive, an increase in the real exchange rate leads some previous non-exporters to begin exporting.

Consider next the response of exports in an economy with financial frictions and all debt denominated in domestic final goods. In this economy a devaluation has the same expansionary effect than in the case above but the response of exports is smaller. First of all, to the extent that exporters are financially constrained, they cannot immediately adjust their overall scale of production since they have to increase their net worth before they can expand their capital stock and their production. This slows down the response of exports to a real depreciation. However, this negative effect of financial frictions is partially compensated by a reallocation channel that is absent in the frictionless economy: since a devaluation leads to an increase in the marginal revenue from exporting, for a given level of total sales, following a devaluation financially constrained firms choose to increase the proportion of their total production sold abroad at the expense of domestic sales. Lastly, while a devaluation induces some non-exporters to start exporting, the entry into the foreign market is smaller compared to the frictionless economy. This is because, as explained above, financial frictions prevent firms from operating at their optimal scale. Thus, while the real depreciation has still only expansionary effects on aggregate exports, these effects are smaller in the model with financial frictions than in the frictionless economy.

Finally, consider the economy with financial frictions but debt denominated in foreign 
goods. In this case, as in the model with financial frictions and debt denominated in domestic goods, a devaluation has expansionary effect on export through an increase in export profits. However, in this case a devaluation has also a contractionary effect. This is because the increase in the real exchange rate increases firms' debt burden in terms of domestic goods, tightening the borrowing constraint of those firms that were already financially constrained, and forcing some previously unconstrained firms to become constrained. This affects negatively both the intensive and extensive export margins and tends to decrease exports.

Thus, in the model with financial frictions and foreign debt, the net impact of a large devaluation on aggregate exports depends on the extent to which firms increase or reduce their overall scale, the extent to which these firms decide to reallocate between the domestic and foreign markets, and the share of firms that begin to export. Therefore, to determine the contribution of financial frictions and foreign-denominated debt to the observed dynamics of aggregate exports in episodes of large devaluations, we quantify their relative importance in the next section.

\section{Quantitative Analysis}

In this section, we study the quantitative implications of our model. We calibrate the model to match key cross-sectional moments of plant-level data and investigate to what extent financial frictions and balance-sheet effects can account for the dynamics of exports observed in the data following large real depreciations.

To answer this question, we study the response of the economy to a sudden and unexpected increase in a real exchange rate caused by a sequence of shocks to the price of foreign final good, $P_{f} \cdot{ }^{11}$ Moreover, to understand the role played by financial frictions and foreign-denominated debt in our setup, we compare our benchmark model a version of the model without financial frictions $(\theta=\infty)$ as well as a version with borrowing constraints but with only domestic-denominated debt.

\subsection{Exporters heterogeneity}

Heterogeneity in export intensity. In our model, firms respond to changes in the real exchange rate by adjusting exports through three channels: (i) given a level of production, firms reallocate their sales from domestic to foreign markets; (ii) exporters expand their foreign sales by increasing production through capital accumulation and by hiring labor;

\footnotetext{
${ }^{11}$ As discussed below, we choose the magnitude of the shocks to $P_{f}$ to match the median devaluation in our sample.
} 
and (iii) some non-exporters start exporting. As explained in the mechanism section, the extent to which firms can reallocate their production depends on their initial export intensity: higher export intensity leaves firms with less scope for reallocation. Therefore, in order to discipline the importance of this channel, we examine the extent of heterogeneity across firms along this dimension.

Table 3: Heterogeneity in export intensity among exporters

\begin{tabular}{cccc}
\hline \hline & \multicolumn{3}{c}{ Exporters } \\
$\mathrm{x} / \mathrm{y}$ & share of X & share of D & share of exporters \\
\hline $0.0-0.6$ & 0.28 & 0.92 & 0.74 \\
$0.6-1.0$ & 0.73 & 0.08 & 0.26 \\
\hline \hline
\end{tabular}

Using Chilean plant-level data, ${ }^{12}$ we find that there is indeed substantial heterogeneity in export intensity across firms. We observe that, while the median export intensity is 0.21 (i.e. the median exporter exports $21 \%$ of his total sales) a substantial fraction of exporters exhibits much higher export intensity, exporting most of their production. Motivated by these observations we divide exporters into two groups based on their export intensity: those with export intensity below $60 \%$ and those with export intensity above $60 \%$. We report the results in Table 3.

We observe that while almost three quarters of exporters have export intensity below 0.6 , these exporters account for only $28 \%$ of aggregate exports. In contrast, the remaining $26 \%$ of exporters with export intensity above 0.6 account for almost three quarters of total exports. Note that the latter group doesn't simply consist of firms that are also larger domestically: these firms account for less than $10 \%$ of aggregate domestic sales.

Heterogeneity in the currency composition of debt. As argued in the empirical section, there is substantial evidence that exporters have a significantly larger share of their liabilities denominated in foreign currency compared to non-exporters. Using balance-sheet data on firms from different Latin-American countries, Martınez and Werner (2002), Benavente et al. (2003), Galiani et al. (2003), Pratap et al. (2003), Carranza et al. (2003), Aguiar (2005), Bleakley and Cowan (2008), all find evidence that exporters tend to have more debt denominated in foreign currency than non-exporters. We find a similar pattern among Peruvian firms (Table 2).

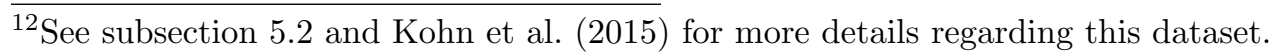


Assumptions. Above we showed that there is substantial heterogeneity in export intensity across firms and that exporters tend to hold more foreign debt than non-exporters. Motivated by this evidence, in the quantitative analysis below, we consider two types of firms: (i) a fraction $\zeta$ of firms that only exports (which we refer to as "only-exporters") and (ii) a fraction $1-\zeta$ that can choose whether to export or not. Since exporters tend to hold more foreign debt than firms that produce for the domestic market, we assume that firms in the first group have all their debt denominated in foreign final goods while the remaining firms have all their debt denominated in foreign currency. That is, we set $\lambda_{X}$, the fraction of debt denominated in foreign final goods among "exporters-only", to 1 , and $\lambda$, the fraction of debt denominated in foreign final goods among remaining firms, to 0. Finally, we assume that firms in the two groups face different trade costs; $\tau_{X}$ and no entry cost for "exporters-only", $\tau$ and $F$ for the remaining firms. The remaining parameters are the same across the two groups.

While we conduct the main quantitative analysis under the assumptions above, we also study how sensitive the results are to these assumptions. We find that the strength of the effects of a large devaluation on aggregate exports crucially depends on the distribution of export intensity and debt across firms.

\subsection{Calibration}

In this subsection, we describe our calibration strategy. We calibrate our model using Chilean plant-level data from the Chilean Annual Manufacturing Survey (ENIA), collected by the National Institute of Statistics (INE) for the years 1995 to 2007, which we supplement with other data sources specified below. ${ }^{13}$ We divide the parameters space in two groups. The parameters in the first group are predetermined, while those in the second group are calibrated to match key moments of the data.

The first group of parameters consists of $\beta, \gamma, \sigma, \rho_{z}, \delta, \alpha, r$, and $\zeta$. We set the risk aversion parameter, $\gamma$, to 2 and the elasticity of substitution across varieties, $\sigma$, equal to 4 . These values fall within the ranges of values that have been used in previous studies. ${ }^{14} \mathrm{We}$ follow Kohn et al. (2015) and set $\beta=0.8, \rho_{z}=0.9, \delta=0.06$, and $\alpha=0.33$. We set the real interest rate to 0.06 , the average real interest rate in Chile over this period according to data from the International Monetary Fund. Finally, we choose $\zeta$, the fraction of firms that only export, to be equal to 0.0546 which implies that firms that only export constitute

\footnotetext{
${ }^{13}$ The Chilean Annual Manufacturing Survey is an annual survey that collects longitudinal data on all manufacturing plants with more than ten workers. For more details see Kohn et al. (2015).

${ }^{14}$ See Guvenen (2006), Blundell et al. (1993) for the intertemporal elasticity of substitutions, Ruhl (2008) for $\sigma$.
} 


\section{Table 4: Parameterization}

\begin{tabular}{cc}
\hline \hline \multicolumn{2}{c}{ Predetermined } \\
$\gamma$ & 2 \\
$\sigma$ & 4 \\
$\delta$ & 0.06 \\
$\alpha$ & 0.33 \\
$\beta$ & 0.8 \\
$\rho_{z}$ & 0.9 \\
$r$ & 0.06 \\
$\zeta$ & 0.055 \\
\hline Calibrated by SMM \\
$\tau_{X}$ & 2.05 \\
$\tau$ & 6.67 \\
$F$ & 0.05 \\
$\sigma_{\varepsilon}$ & 0.28 \\
$\theta$ & 0.36 \\
\hline \hline
\end{tabular}

$26 \%$ of exporters. This value corresponds to the share of exporters accounted by firms with export intensity higher than $60 \%$ in the data.

The second group of parameters consists of the fixed cost of exporting, $F$; the variable cost of exporting faced by firms that can produce for both domestic and foreign market, $\tau$; the variable cost of exporting for firms that only export, $\tau_{X}$; the standard deviation of productivity shocks, $\sigma_{\varepsilon}$; and the collateral constraint parameter, $\theta$. We choose them to match the following moments: $(i)$ share of exporters, $(i i)$ aggregate exports to aggregate sales ratio, (iii) aggregate exports accounted by firms that export more than $60 \%$ of their total sales, $(i v)$ volatility of log sales, and $(v)$ credit to value-added ratio. We compute target moments $(i)$ to $(i v)$ using the Chilean plant-level data described above. For (v), we obtain the total external finance from Superintendencia de Bancos e Instituciones Financieras de Chile,$^{15}$ and value-added from Chilean plant-level data.

Calibration Strategy. The parameters that we use in our calibration are presented in Table 4, while the target moments and their model counterparts are presented in Table 5. To calibrate the model, we follow a Simulated Method of Moments approach. We choose the parameters to minimize the objective function $M W M^{\prime}$, where $M$ is a row vector of the logdifference between each target moment and its model counterpart. $W$ is a weighting matrix

\footnotetext{
${ }^{15}$ Total credit balances for manufactures, corresponding to the sectors in our plant-level data.
} 
that allocates the same weight to each of the cross-sectional moments $(i)$ to $(v)$. Table 5 shows that the model is able to match the target moments almost exactly.

Table 5: Target moments

\begin{tabular}{ccc}
\hline \hline & Data & Model \\
\hline Share of exporters & 0.21 & 0.21 \\
Exports/sales & 0.25 & 0.25 \\
Exports $X /$ Exports & 0.73 & 0.73 \\
Sd log sales & 1.75 & 1.75 \\
Credit/sales & 0.33 & 0.33 \\
\hline \hline
\end{tabular}

\subsection{Large devaluation}

In this section, we investigate the response of the economy to an unexpected increase in the real exchange rate - real depreciation- caused by an increase in the price of the foreign final good, $P_{f} \cdot{ }^{16}$ We consider a situation where the economy is initially in a stationary equilibrium and firms expect that this situation will continue forever. We then unexpectedly change the aggregate foreign price, $P_{f}$, and compute the dynamic response of our model to this shock.

To approximate the behavior of the real exchange rate observed in the data, we assume that the price of the final foreign good increases gradually. In particular, we study an unexpected increase in $P_{f}$ from 1 to 1.4 in period 2, and an additional anticipated increase to 1.8 , its final value, in period 3. As a result of these shocks, the real exchange rate increases by approximately $35 \%$, a value close to the one observed in the data.

To understand the role played by the foreign debt and borrowing constraints in shaping the response of the economy to a change in the real exchange rate, we compare the dynamics implied by our benchmark model with the dynamics implied by a model with financial frictions and debt denominated in domestic goods $\left(\theta=0.36\right.$ and $\left.\lambda=\lambda_{X}=1\right)$, as well as with those implied by a model without borrowing constraints $\left(\theta=\infty\right.$ and $\left.\lambda=\lambda_{X}=1\right)$. This exercise allows us to understand the role played by balance-sheet effects and financial frictions in shaping the response of aggregate exports to a real devaluation.

Timing of the shock. The shock to the price of foreign final good occurs in period 2 after entrepreneurs have hired labor and made their production decisions (i.e., after they chose $n$

\footnotetext{
${ }^{16}$ Recall from section 2.1.3 that the real exchange rate, $\xi$, is equal to $\frac{P_{f}}{P}$. Thus, an increase in $P_{f}$ tends to increase the real exchange rate to the extent that domestic price level responds less than one-to-one. To ensure that this is the case and, hence, to generate a real devaluation, we keep the foreign price of imports, $p_{m}$, constant.
} 
and produced their domestic and foreign output, $y_{h}$ and $\left.y_{f}\right)$ but before final good production and entrepreneurs' consumption-saving decisions take place. We present the exact timing in period 2 in Figure 4 and explain it in more details below.

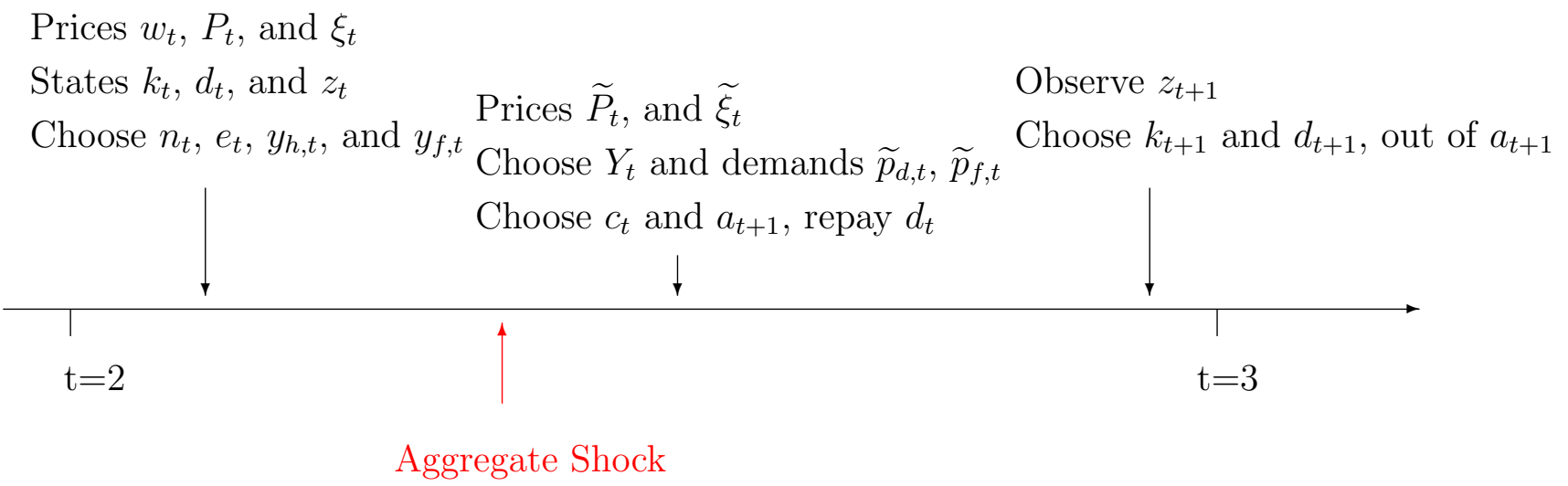

\section{Figure 4: Timing of devaluation}

As shown in Figure 4, at the beginning of period 2 entrepreneurs make their hiring and production decisions expecting the price of the domestic final good and the exchange rate to stay at their respective steady state levels, $P$ and $\xi$. In particular, they decide how much of their output to sell domestically and how much of it to export. Once the entrepreneurs production took place, the shock to the price of the foreign final good occurs. At the time of the shock, all agents learn that the foreign price increases from 1 to 1.4 in period 2 and that it will increase further from 1.4 to 1.8 in period 3, staying at its new level thereafter. Thus, at the time of the shock all agents learn the deterministic path of $P_{f}$ from that point onwards.

After the increase in $P_{f}$, final good producers decide how much of the final good to produce. They also decide how much of the domestic versus imported intermediates to purchase, leading to an adjustment of prices and profits from intermediate production, according to the new demands from final good producers. In response to the choices of final good producers, the price of the intermediate goods, the final domestic good, and the exchange rate adjust to their new levels, $\widetilde{p}_{d, t}, \widetilde{p}_{f, t}, \widetilde{P}_{t}$ and $\widetilde{\xi}_{t}$, respectively.

Once final goods production takes place, entrepreneurs collect their profits, choose their consumption and net worth, repay their old debt at the new exchange rate, and, if they choose to export, they also pay the fixed costs of exporting, resulting in the following budget constraint: 


$$
c+a^{\prime}+d\left[\lambda+(1-\lambda) \frac{\xi}{\xi_{-1}}\right]-(1-\delta) k=w+p_{h} y_{h}+e \xi \frac{p_{f}}{P_{f}} y_{f}-w n-e F
$$

At the end of the period, firms observe their idiosyncratic productivity for the following period, $z^{\prime}$, and choose how much capital and debt to carry on to the following period, out of the new worth $a^{\prime}$.

\subsection{Results}

Main results. We first investigate the behavior of the real exchange rate following an increase in the price of the foreign final good and compare its dynamics across the three models mentioned above: (i) our benchmark model with borrowing constraints, debt denominated in foreign final goods for the "exporters only" firms, and debt denominated in domestic final goods for the remaining firms (i.e. $\theta=0.36, \lambda=1, \lambda_{X}=0$ ); (ii) an economy with borrowing constraints and debt denominated in domestic goods for all firms (i.e. $\theta=0.36, \lambda=1, \lambda_{X}=1$ ); and (iii) an economy without borrowing constraints and debt denominated in domestic goods (i.e. $\theta=\infty, \lambda=1, \lambda_{X}=1$ ).

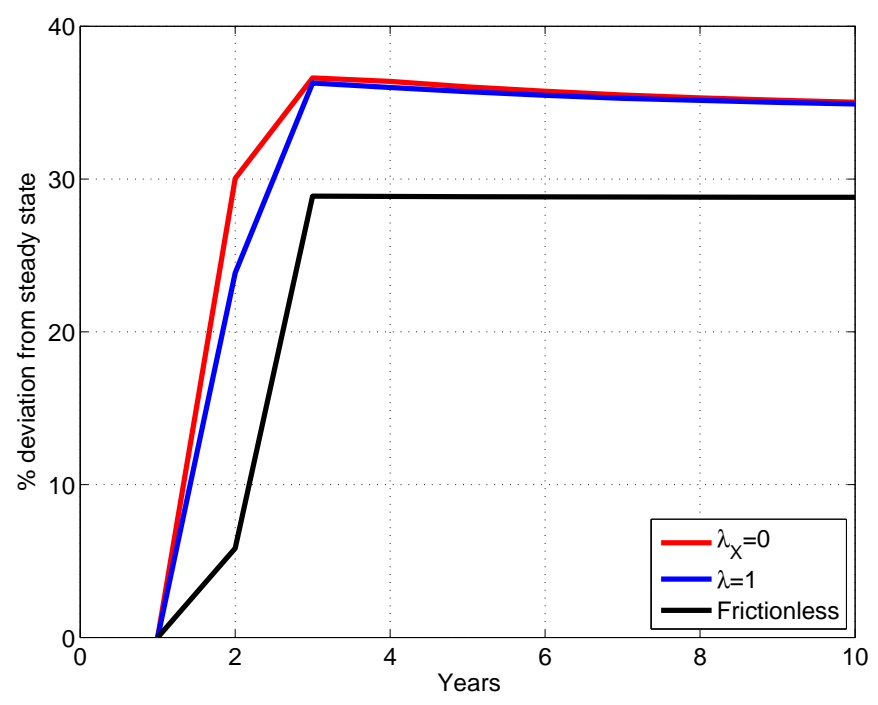

Figure 5: Real exchange rate

Figure 5 plots the percentage deviation of the real exchange rate from its steady state for each of the economies, following the shock to the price of the foreign final good. We see that, in the benchmark model, the exchange rate increases on impact by $30 \%$, followed by an additional $6 \%$ increase in period three, and stays relatively constant afterwards. The 
exchange rate follows a similar pattern in the model with financial frictions but only domestic debt, except that its initial response is smaller (it increases on impact by 24\%). Finally, in the frictionless case the real exchange rate increases only by $6 \%$ in period 2 , before reaching its new steady state level in period 3, 29\% above its initial level. Thus, the same shock generates a smaller real exchange rate increase in the economy without financial frictions compared to the economies with borrowing constraints.

Next, we consider the response of exports to these changes in the real exchange rate. Since, as shown above, the same shock generates different responses of the exchange rate across our three models, we focus on the elasticity of exports to the change in the real exchange rate relative to the initial stationary equilibrium. ${ }^{17}$ This not only allows us to compare the response of exports across the models but also to compare them with the data.

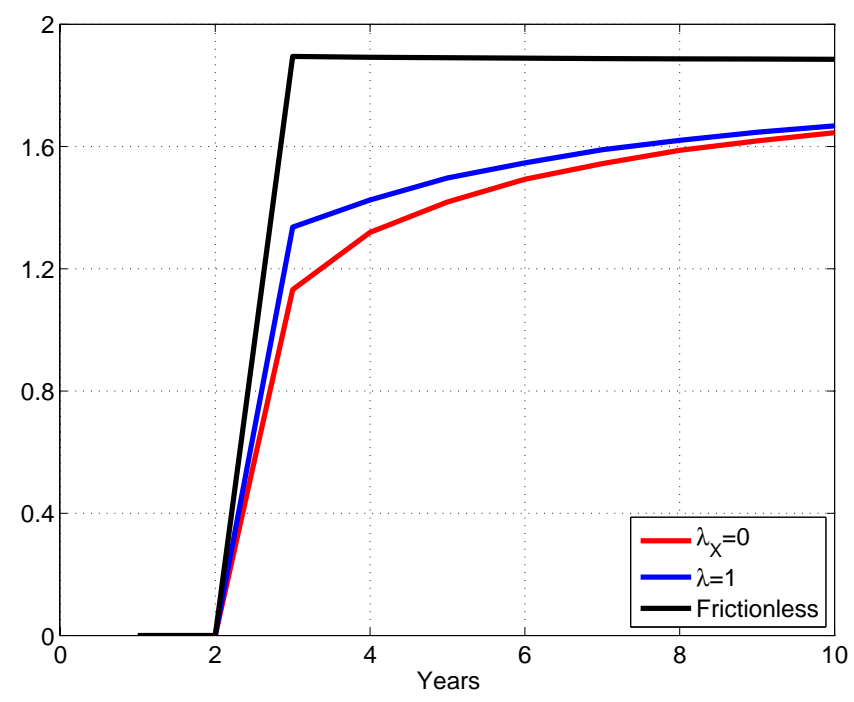

Figure 6: Elasticity of Exports to RER

Figure 6 plots the response of exports in the three models described above. First, note that in the economy without financial frictions aggregate exports adjust to their new stationary equilibrium level as soon as firms are able to adjust their exports in period 3. Thus, a standard model with fixed costs but without borrowing constraints predicts that exports adjust immediately to the change in the real exchange rate. This stands in stark contrast to the gradual increase observed in the data, as shown in Figure $1 .{ }^{18}$

${ }^{17}$ The elasticity of exports to the real exchange rate is computed as $E_{x, r e r}=\frac{\ln \left(X_{t+k}\right)-\ln \left(X_{t}\right)}{\ln \left(R E R_{t+k}\right)-\ln \left(R E R_{t}\right)}$ for $k>2,3, \ldots$, where $t$ is the pre-devaluation period. This is the same object that we considered in the empirical section, Figure 1.

${ }^{18}$ We do not consider sunk costs in this model. However, even in the presence of sunk costs, but in the absence of additional aggregate shocks, exports adjust immediately to changes in the real exchange rate. 
In the case of financial frictions and debt denominated only in domestic units (line $\lambda=1$ in Figure 6), not only is the exports elasticity significantly lower than in the frictionless economy in period 3, but it also grows slowly towards its long-run equilibrium value, thus generating a pattern closer to the one observed in the data. In particular, for each onepercent increase in the real exchange rate, aggregate exports increase by $1.34 \%$ in period 3 , a value $30 \%$ lower than its frictionless counterpart, 1.89 , and substantially closer to the empirical elasticity. Thereafter, the elasticity of exports to the real exchange rate increases slowly to its final value of 1.75 . This result suggests that financial frictions significantly slow down the aggregate exports adjustment to its new steady state value.

Finally, we consider our benchmark model (line $\lambda_{X}=0$ in Figure 6) where firms in the "exporters only" group have all of their debt denominated in foreign units and, hence, their net worth is hit when the real exchange rate increases. ${ }^{19}$ We observe that in this case, the export elasticity is only 1.13 in period 3, $16 \%$ lower than in the economy with only domestic debt and $40 \%$ lower than in the model without financial frictions. Thereafter, the export elasticity increases slowly to its new long-run value of 1.75 (the same long-run level as in the model with financial frictions and only domestic debt), but stays below the export elasticity implied by the model with financial frictions and only domestic debt throughout this adjustment. Therefore, we see that the model with financial frictions and balance sheet effects (i.e., our benchmark model) generates a response of exports that is closest to the behavior of exports observed in the data.

Effects of the real depreciation on other aggregate variables. Above, we showed that financial frictions slow down the adjustment of aggregate exports, and that foreigndenominated debt amplifies this effect. We now describe the effects of the real depreciation on other aggregate variables such as credit, GDP, investment, and net exports.

As explained in the mechanism section, while a real exchange rate depreciation induces an increase in exports by increasing firms' export profits in terms of the domestic final good, it also has a contractionary effect on exports. First, it reduces firms' net worth, making the borrowing constraint tighter exactly when firms want to expand their capital and production. Second, if the shock creates a persistent devaluation so that further devaluation is expected in the near future, it increases the opportunity cost of capital for firms borrowing in foreign goods.

For an analysis of the exports response under sunk costs and additional aggregate shocks, see Alessandria et al. (2014).

${ }^{19}$ Even in the benchmark calibration, where aggregate net assets are close to zero for the "exporters only" firms, there is a substantial effect through a decrease in firms' net worth. This is because, even though some of these firms have more assets than debt, this is not the case for the constrained exporters, which are the ones affected by the lower net worth through a binding borrowing constraint. 


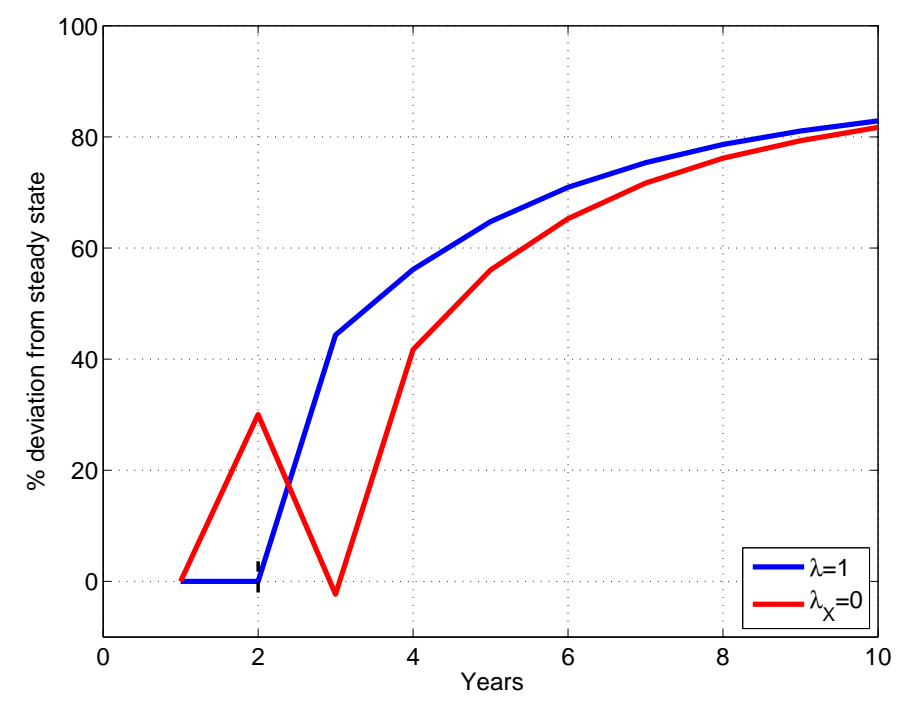

Figure 7: Total Credit of Firms that Only Export

Figure 7 shows the dynamics of total credit for "exporters only" firms in our benchmark model (line $\lambda_{X}=0$ ) and in the model with financial frictions but only domestic debt (line $\lambda=1)$. We see that in the benchmark model the real depreciation causes a reduction in net worth resulting in an increase in credit in period 2 due to the higher value of credit in terms of domestic units. In period 3, credit decreases sharply, due to a fall in investment by the firms for which the borrowing constraint became more binding. Thereafter credit increases slowly following the increase in capital and production. In contrast, in the economy with only domestic debt, credit increases monotonically to its new steady state, following the increase in production.

Next, we consider the effect of an increase in the real exchange rate on GDP, consumption, investment and net exports over GDP. Figure 8 shows that, following a shock to the price of the foreign final good, GDP and consumption increase gradually both in our benchmark model and in the model with only domestic debt. However, in the benchmark model, both aggregates are below their counterparts in the model with only domestic debt, though they ultimately converge to the same stationary equilibrium. 

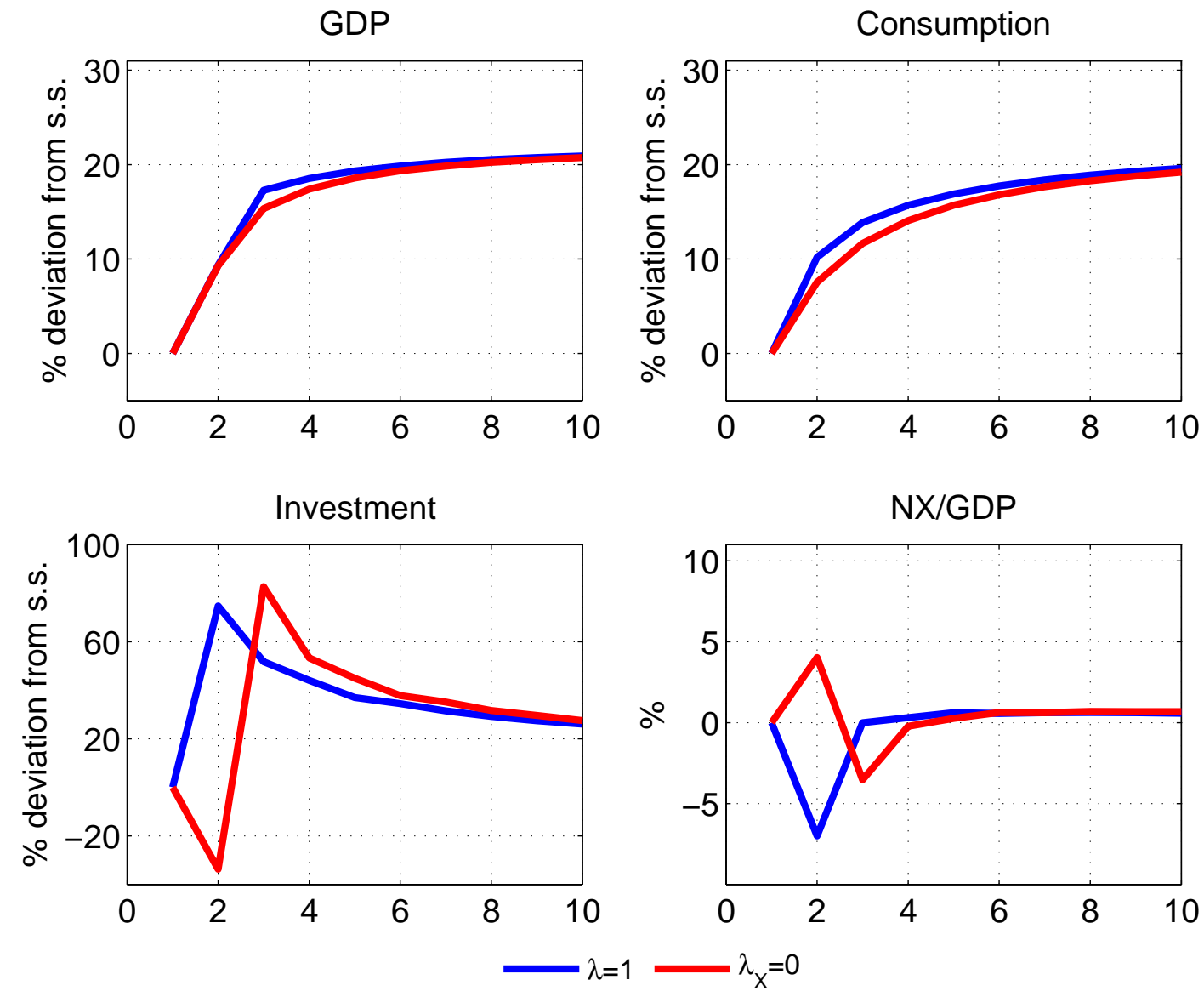

Figure 8: GDP Components 
In contrast, investment and net exports over GDP differ substantially across the two economies. While in the model with only domestic debt, following the aggregate shock there is a sharp increase in investment and a decline in net exports, in the presence of foreign debt (the benchmark model), investment and net exports over GDP follow the opposite paths. In particular, in our benchmark model investment drops in period 2 before rebounding in period 3 while net exports relative to GDP increases in period 2 before falling in period 3 . Investment drops as a result of the lower net worth of constrained firms and the higher opportunity cost of capital due to the expected further real exchange rate depreciation between periods 2 and 3. The increase in the net exports over GDP in the model with foreign debt (expressed in terms of the domestic final good) is driven by a large increase in the exchange rate. On the other hand, a relatively small increase in the exchange rate in period 2 is responsible for a fall in net exports over GDP in the model with only domestic debt (see Figure 5). Finally, once the exchange rate settles at a similar level in the two models in period 4 the ratio of net exports to GDP reach similar levels in both models.

\subsection{Robustness}

As explained above, we made two stark assumptions in the benchmark calibration of our model: we assumed that there is a fraction of firms that only export, and also assumed that these firms only issue debt denominated in foreign goods. While both of these assumptions were motivated by our plant-level evidence and by earlier empirical findings in the literature, we now investigate the extent to which our results depend on these assumptions. In addition, we examine the behavior of the real exchange rate and aggregate exports to a one-time shock in the price of foreign final good (rather than the gradual shock that we considered above).

All debt denominated in foreign goods. We first analyze the effect of a real exchange rate depreciation on exports in the case where all firms have foreign-denominated debt. In Figure 9 we depict the elasticity of exports to the exchange rate in this model (line $\lambda=0$ in Figure 9) and compare it with our benchmark model (foreign debt among "only export" firms and domestic debt among the rest of the firms, line $\lambda_{X}=0$ in Figure 9), and the model with all debt denominated in domestic goods (line $\lambda=1$ ).

Surprisingly, we find that when all firms borrow in foreign goods, the elasticity of aggregate exports is close to the implied by the model with only domestic debt, and above the elasticity implied by the model where only a fraction $\zeta$ of firms has foreign debt. To understand why this is the case, note that when all firms hold foreign debt then the devaluation also has a negative effect on domestic producers by increasing the value of their liabilities when expressed in terms of domestic final good. However, in contrast to the firms 


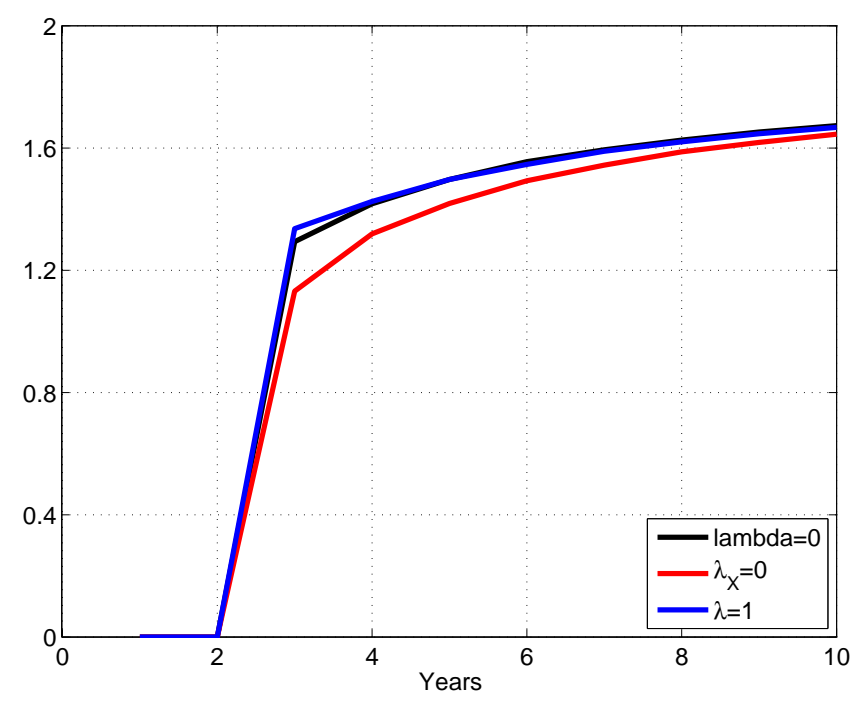

Figure 9: Elasticity of Exports to RER

that export, domestic producers do not enjoy the benefit that comes from the increase in the foreign demand for domestic good. ${ }^{20}$ Consequently, domestic firms are hit hard by the devaluation and decrease their labor demand leading to a fall in the wage. Exporters take advantage of this and hire more labor, increasing both their total production and exports by more than in the case when a devaluation did not affect adversely domestic firms. This translates into a higher export elasticity compared to our benchmark model.

No export intensity heterogeneity. Above we assumed that there are two types of firms that differ with respect to their export intensity: (i) firms that only export and hence have export intensity of $100 \%$ and (ii) firms that can both produce for the domestic and for the foreign markets. We now analyze the robustness of the results to the alternative assumptions regarding heterogeneity in export intensity.

Figure 10 below compares export elasticity implied by a model with financial frictions and only foreign debt under three different assumptions regarding export intensity heterogeneity: (i) the benchmark economy with two types of exporters (marked Baseline in Figure 10), (ii) an economy with only one type of firms where all firms can both export and produce domestically (corresponding to the assumption that $\zeta=0$ in our model, line $\zeta=0$ in Figure 10), and (iii) an economy with two types of firms where one type of firms can only export and the other type of firms can only produce for domestic market (i.e., in terms of

\footnotetext{
${ }^{20}$ For simplicity, in the argument we abstract from entry into foreign export market and assume that these firms only produce domestically. However, given that even after a large shock entry into exporting is limited (partly due to the presence of financial frictions), the same argument holds in the case where there is entry into the foreign market.
} 
our model parameters $\zeta=0.21, \tau_{X}<\infty$ and $\tau=\infty$, line $\zeta=0.21$ in Figure 10). ${ }^{21}$

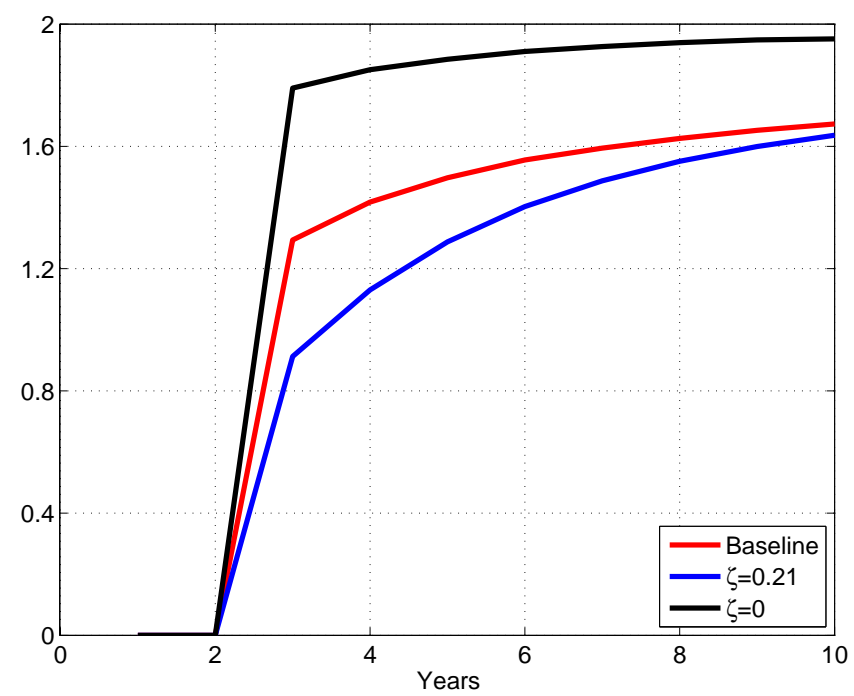

Figure 10: Elasticity of Exports to RER

Note that the case (ii) above (i.e. $\zeta=0$ ) corresponds to standard trade models with only one type of firms, but with financial frictions, where either iceberg costs, $\tau$, or the size of the foreign economy, $P_{f} Y_{f}$, are calibrated to match the average export intensity. As Figure 10 shows, in this case the export elasticity is almost as high as in the frictionless model. This result is driven by the reallocation of production towards foreign sales by continuing exporters. Since firms only use one-fourth of their resources (capital and labor) to produce for the foreign market, they are able to reallocate their production from the domestic to the foreign market even holding their total output unchanged (i.e., even in the case in which they have a binding borrowing constraint). ${ }^{22}$

On the other extreme, consider the case in which a fraction $\zeta$ of firms only export, and the remaining firms produce only domestically -model (iii) above (line $\zeta=0.21$ in Figure 10). In this case, the export elasticity in period 3 is $30 \%$ lower than in the benchmark model with with $\lambda=0$ and $\lambda_{X}=0$. In this case, there are no firms that produce for both markets, and, thus, not only firms cannot reallocate their production at all, but there is also no entry into exporting (i.e., no adjustment in the extensive margin). Therefore, the only way firms can increase their exports is by hiring labor and by expanding their physical capital. However, as their physical capital declines following a decrease in net worth, caused by an increase in

${ }^{21}$ Models (i) and (ii) were calibrated separately using the strategy described in subsection 5.2 with the exception that we dropped Export ${ }_{X} /$ Exports from the target moments.

${ }^{22}$ See also the mechanism section for the connection between firm-level export intensity and the strength of the reallocation channel. 
the value of the foreign debt, this adjustment is severely suppressed and the resulting export elasticity is very low.

One-time shock. Finally, we now consider a one-time increase in the price of foreign final goods, instead of the gradual increase considered above. Figure 11 compares the behavior of the real exchange rate and the exports elasticity implied by our benchmark model under these two alternative experiments.
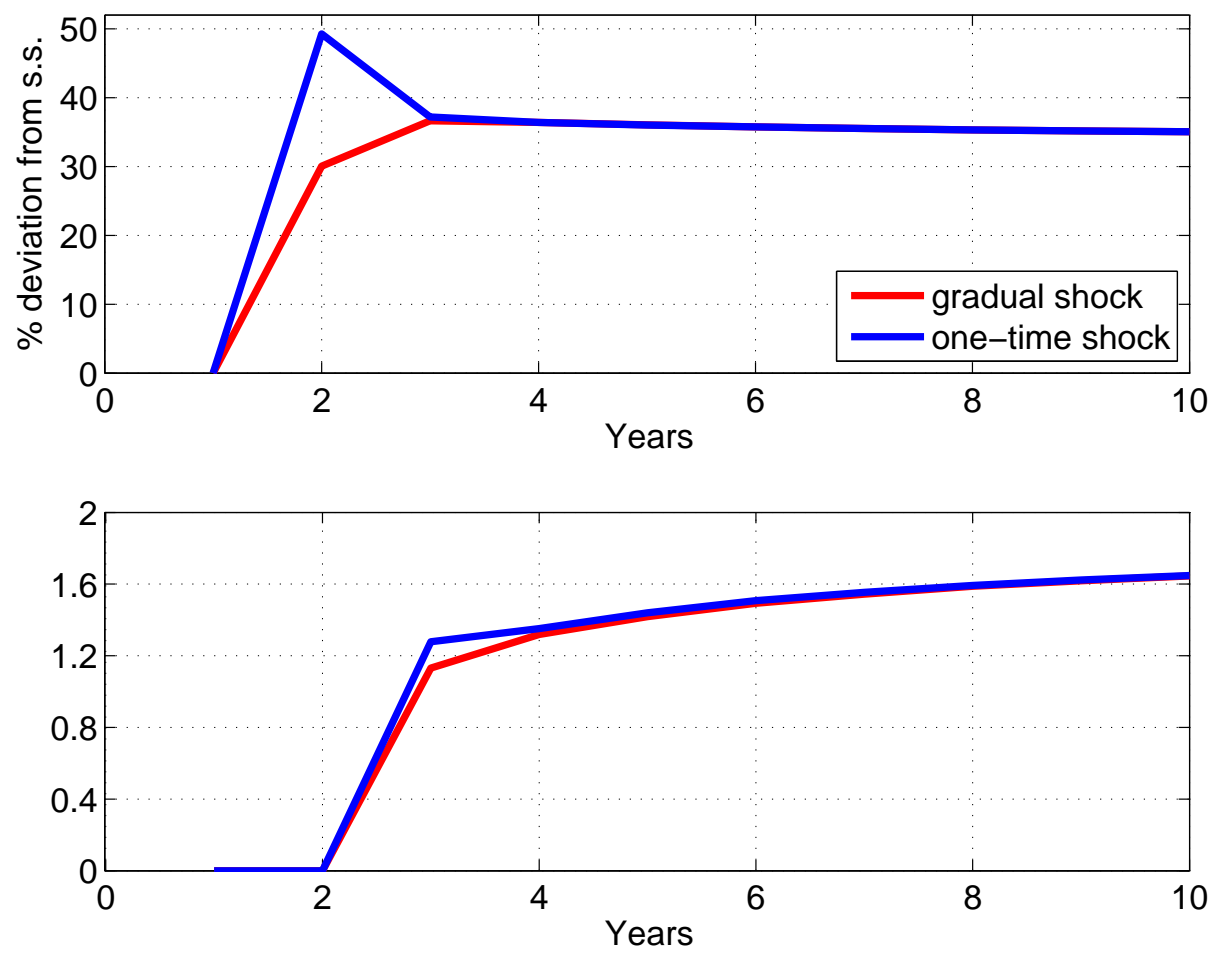

Figure 11: Elasticity of Exports to RER

As we discussed above, the gradual shock generates a real exchange rate depreciation in periods 2 and 3, with a persistent but small appreciation thereafter. In contrast, in the case of a one-time shock, the real exchange rate depreciates sharply in period 2, but it sharply appreciates between periods 2 and 3, after which the two models generates very similar paths for the exchange rate.

As a consequence, in the case of the one-time shock, the exports elasticity is higher in period 3 than in the gradual-shock case. From period 4 onwards the evolution of the real exchange rate in both cases in very similar. The larger increase in the exports elasticity on impact is due to the effect of a lower opportunity cost of capital in period 2, as firms now expect an appreciation that decreases the effective rate of return they have to pay on their 
foreign debt. Nevertheless, the overall behavior of the exports elasticity, the ranking among the different economies, and the other results presented above, remain valid under this one time shock.

\section{Conclusion}

In this paper, we ask: to what extent do financial frictions and balance-sheet effects explain export dynamics in large devaluations? To answer this question, we set up a standard trade model à la Melitz (2003), introduce financial frictions and foreign-denominated debt, and investigate the response of aggregate exports to a large real depreciation.

Our results suggest that financial frictions slow down aggregate exports following large real depreciations. Financial frictions reduce the scale and profitability of firms with respect to their optimal level, thus reducing the foreign sales of exporting firms and the rate of entry of new firms to the export market. Foreign-denominated debt amplifies this effect by reducing the net-worth of firms, as a result of the devaluation, just when firms want to increase their scale. We find that these effects are quantitatively significant: a model with financial frictions and debt denominated in foreign units can explain up to 45 percent of the gap in the response of exports, on impact, between the data and a frictionless version of the model.

The strength of these effects depends on the assumed distribution of export intensity in the model. Without export intensity heterogeneity, standard calibrations imply no effects of financial frictions and foreign-denominated debt on exports. This is because firms export a small share of their total sales and, thus, are able to reallocate production from domestic to foreign sales, even without expanding their overall scale.

While our results have important policy implications, we also believe that they contribute to a better understanding of the balance-sheet effects on firms' production decisions, a question that has been elusive due to the difficulty of finding detailed data on both balance-sheets and production decisions. 


\section{References}

Aghion, P., P. Bacchetta And A. Banerjee, "A simple model of monetary policy and currency crises," European Economic Review 44 (2000), 728-738.

—_, "Currency crises and monetary policy in an economy with credit constraints," European Economic Review 45 (2001), 1121-1150.

— - "A corporate balance-sheet approach to currency crises," Journal of Economic Theory 119 (2004), 6-30.

Aguiar, M., "Investment, devaluation, and foreign currency exposure: The case of Mexico," Journal of Development Economics 78 (2005), 95-113.

Alessandria, G., S. Pratap and V. Z. Yue, "Export dynamics in large devaluations," Working Paper, 2014.

Bebczuk, R., A. Galindo and U. PanizzA, "An evaluation of the contractionary devaluation hypothesis," (2006).

Benavente, J. M., C. A. Johnson and F. G. Morande, "Debt composition and balance sheet effects of exchange rate depreciations: a firm-level analysis for Chile," Emerging Markets Review 4 (2003), 397-416.

Bleakley, H. And K. Cowan, "Corporate dollar debt and depreciations: much ado about nothing?," The Review of Economics and Statistics 90 (2008), 612-626.

Blundell, R., C. Meghir and P. Neves, "Labor Supply and Intertemporal Substitution," Journal of Econometrics 59 (1993), 137-160.

Caballero, R. J. and A. Krishnamurthy, "Excessive dollar debt: Financial development and underinsurance," The Journal of Finance 58 (2003), 867-894.

Caggese, A. And V. Cunat, "Financing Constraints, Firm Dynamics, Export Decisions, and Aggregate Productivity," Review of Economic Dynamics 16 (January 2013), 177-193.

Carranza, L. J., J. M. Cayo and J. E. Galdón-SÁnchez, "Exchange rate volatility and economic performance in Peru: a firm level analysis," Emerging Markets Review 4 (2003), 472-496.

Céspedes, L. F., "Financial frictions and real devaluations," Documentos de Trabajo (Banco Central de Chile) (2005), 1-42. 
Céspedes, L. F., R. Chang and A. Velasco, "IS-LM-BP in the Pampas," IMF Staff Papers (2003), 143-156.

__, "Balance Sheets and Exchange Rate Policy," American Economic Review 94 (2004), 1183-1193.

Chaney, T., "Liquidity Constrained Exporters," NBER Working Papers 19170, 2013.

Cooper, R. N., "Currency devaluation in developing countries," (1971).

Devereux, M. B., P. R. Lane and J. Xu, "Exchange Rates and Monetary Policy in Emerging Market Economies," The Economic Journal 116 (2006), 478-506.

Eaton, J. And S. Kortum, "Technology, geography, and trade," Econometrica 70 (2002), $1741-1779$.

Echeverry, J. C., L. Fergusson, R. Steiner and C. Aguilar, "Dollardebt in Colombian firms: are sinners punished during devaluations?," Emerging Markets Review 4 (2003), 417-449.

Edwards, S., "Are Devaluations Contractionary?," The Review of Economics and Statistics 68 (1986), 501-508.

Frankel, J. A., "Mundell-Fleming Lecture: Contractionary Currency Crashes in Developing Countries," IMF Staff Papers (2005), 149-192.

Galiani, S., E. Levy Yeyati and E. Schargrodsky, "Financial dollarization and debt deflation under a currency board," Emerging Markets Review 4 (2003), 340-367.

Galindo, A., U. Panizza and F. Schiantarelli, "Debt composition and balance sheet effects of currency depreciation: a summary of the micro evidence," Emerging Markets Review 4 (2003), 330-339.

Gertler, M., S. Gilchrist and F. M. Natalucci, "External constraints on monetary policy and the financial accelerator," Journal of Money, Credit and Banking 39 (2007), 295-330.

Guvenen, F., "Reconciling conflicting evidence on the elasticity of intertemporal substitution: A macroeconomic perspective," Journal of Monetary Economics 53 (2006), 14511472 .

Kamin, S. B. And M. KlaU, "Some multi-country evidence on the effects of real exchange rates on output," FRB International Finance Discussion Paper (1998). 
Kohn, D., F. Leibovici And M. Szkup, "Financial Frictions and New Exporter Dynamics," Accepted at the International Economic Review, 2015.

Krugman, P., "Balance sheets, the transfer problem, and financial crises," in International finance and financial crises (Springer, 1999), 31-55.

Leibovici, F., "Financial Development and International Trade," mimeo, 2015.

Manova, K., "Credit Constraints, Heterogeneous Firms, and International Trade," Review of Economic Studies 80 (April 2013), 711-744.

Martinez, L. And A. Werner, "The exchange rate regime and the currency composition of corporate debt: the Mexican experience," Journal of Development Economics 69 (2002), $315-334$.

Melitz, M. J., "The Impact of Trade on Intra-Industry Reallocations and Aggregate Industry Productivity," Econometrica 71 (November 2003), 1695-1725.

Paravisini, D., V. Rappoport, P. Schnabl and D. Wolfenzon, "Dissecting the effect of credit supply on trade: Evidence from matched credit-export data," The Review of Economic Studies 82 (2015), 333-359.

Pratap, S., I. Lobato and A. Somuano, "Debt composition and balance sheet effects of exchange rate volatility in Mexico: a firm level analysis," Emerging Markets Review 4 (2003), 450-471.

Pratap, S. and C. Urrutia, "Firm dynamics, investment, and debt portfolio: balance sheet effects of the Mexican crisis of 1994," Journal of Development Economics 75 (2004), $535-563$.

Ruhl, K. J., "The International Elasticity Puzzle," NYU Stern School of Business, 2008. 